\title{
Temperature modulates the response of the thermophilous sea urchin Arbacia lixula early life stages to $\mathrm{CO}_{2}$-driven acidification
}

\author{
Paola Gianguzza ${ }^{a}$, Giulia Visconti ${ }^{\text {a,* }}$, Fabrizio Gianguzza ${ }^{b}$, Salvatrice Vizzini ${ }^{a}$, \\ Gianluca Sarà ${ }^{\mathrm{a}}$, Sam Dupont ${ }^{\mathrm{c}}$ \\ ${ }^{a}$ Dipartimento di Scienze della Terra e del Mare (DiSTeM), Università di Palermo, Via Archirafi, 22, I-90123 Palermo, Italy \\ ${ }^{\mathrm{b}}$ Department of Molecular and Biomolecular Technologies Sciences (STEMBIO), University of Palermo, 90128 Palermo, Italy \\ ${ }^{\mathrm{c}}$ Department of Biological and Environmental Sciences, University of Gothenburg, The Sven Lovén Centre for Marine Sciences, 45178 Fiskebäckskil, Sweden
}

\section{A R T I C L E I N F O}

\section{Article history:}

Received 29 March 2013

Received in revised form

18 July 2013

Accepted 24 July 2013

\section{Keywords:}

Climate change

Ocean warming

Ocean acidification

Calcification

Sea urchin

\begin{abstract}
A B S T R A C T
The increasing abundances of the thermophilous black sea urchin Arbacia lixula in the Mediterranean Sea are attributed to the Western Mediterranean warming. However, few data are available on the potential impact of this warming on A. lixula in combination with other global stressors such as ocean acidification. The aim of this study is to investigate the interactive effects of increased temperature and of decreased $\mathrm{pH}$ on fertilization and early development of $A$. lixula. This was tested using a fully crossed design with four temperatures $\left(20,24,26\right.$ and $27^{\circ} \mathrm{C}$ ) and two $\mathrm{pH}$ levels ( $\mathrm{pH}_{\mathrm{NBS}} 8.2$ and 7.9). Temperature and $\mathrm{pH}$ had no significant effect on fertilization and larval survival (2d) for temperature $<27{ }^{\circ} \mathrm{C}$. At $27{ }^{\circ} \mathrm{C}$, the fertilization success was very low $(<1 \%)$ and all larvae died within $2 \mathrm{~d}$. Both temperature and $\mathrm{pH}$ had effects on the developmental dynamics. Temperature appeared to modulate the impact of decreasing $\mathrm{pH}$ on the \% of larvae reaching the pluteus stage leading to a positive effect (faster growth compared to $\mathrm{pH}$ 8.2) of low pH at $20^{\circ} \mathrm{C}$, a neutral effect at $24^{\circ} \mathrm{C}$ and a negative effect (slower growth) at $26{ }^{\circ} \mathrm{C}$. These results highlight the importance of considering a range of temperatures covering today and the future environmental variability in any experiment aiming at studying the impact of ocean acidification.
\end{abstract}

(c) 2013 Elsevier Ltd. All rights reserved.

\section{Introduction}

Since the beginning of the industrial revolution and the extensive use of fossil fuels, global atmospheric $\mathrm{CO}_{2}$ concentration has increased from 280 to $380 \mathrm{ppm}$ and is expected to double by 2100 with well described consequences for climate (global warming, increase in extreme events frequency, etc.). The ocean represents a major sink and absorbs half of the excess of $\mathrm{CO}_{2}$. This continued uptake of $\mathrm{CO}_{2}$ alters the carbonate chemistry of the ocean and increases the concentration of hydrogen ions, thereby reducing $\mathrm{pH}$, a phenomenon called ocean acidification (Caldeira and Wickett, 2003). The mean global surface temperature has increased $0.76{ }^{\circ} \mathrm{C}$ in the past 150 years and is predicted to rise an additional $1.1^{\circ} \mathrm{C}-6.4{ }^{\circ} \mathrm{C}$ by the end of the twenty-first century (IPCC, 2007;

\footnotetext{
* Corresponding author. Tel.: +39 (0) 9123862857; fax: +39 (0) 9123891847. E-mail addresses: paola.gianguzza@unipa.it (P. Gianguzza), giulia.visconti@ gmail.com, giulia.visconti@unipa.it (G. Visconti), fabrizio.gianguzza@unipa.it (F. Gianguzza), salvatrice.vizzini@unipa.it (S. Vizzini), gianluca.sara@unipa.it (G. Sarà), sam.dupont@bioenv.gu.se (S. Dupont).
}

Fabry et al., 2008). Ocean acidification scenarios project a $\Delta \mathrm{pH}=-0.3$ to -0.5 units by the end of the century.

The influence of temperature and $\mathrm{pH}$ on echinoderms is well documented as single stressors (e.g. Dupont et al., 2010a; Byrne, 2011; Dupont and Thorndyke, 2013). Temperature impacts metabolisms and modulates performance (Byrne, 2011). Direct impacts of ocean acidification on sea urchins are mostly negative but sub-lethal. These include slower somatic and gonadal growth and reflect a shift in energy budgets linked to additional costs for extracellular $\mathrm{pH}(\mathrm{pHe})$ and intracellular $\mathrm{pH}(\mathrm{pHi})$ regulations rather than direct impact on calcification (Dupont and Thorndyke, 2013). However, interaction between temperature and ocean acidification was only considered in a limited number of studies (Sheppard Brennand et al., 2010; Byrne et al., 2009, 2010a,b; 2011; Caldwell et al., 2011; Catarino et al., 2012a; Ericson et al., 2012; Foo et al., 2012). From this limited dataset, it appears that interaction between temperature and ocean acidification is complex from temperature being the main driver of change to temperature amplifying or diminishing the negative effects of ocean acidification. For example, in adult Paracentrotus lividus oxygen uptake was increased under ocean acidification at $10{ }^{\circ} \mathrm{C}$ but not at $16{ }^{\circ} \mathrm{C}$ (Catarino et al., 2012a). Warming seemed to diminish the negative 
effect of acidification on Tripneustes gratilla larval growth (Sheppard Brennand et al., 2010). Pörtner and Farrell (2008) developed a theoretical framework to predict the combined impact of temperature and ocean acidification. All organisms live within a limited range of body temperatures, due to optimized structural and kinetic coordination of molecular, cellular, and systemic processes, and functional constraints result at temperature extremes. It is hypothesized that synergistic stressors like ocean acidification have the potential to narrow these thermal windows. This theoretical framework highlights the fact that response to ocean acidification can be highly dependent upon thermal conditions. This can explain apparently conflicting results. For example, warming may lead to increased resilience to ocean acidification in experiments done at the lower end of the optimal temperature range of the species, but can enhance sensitivity when an experiment is done close to the upper limit of the thermal tolerance. It is then critical, in any experimental design, to cover the natural range of present and future thermal ranges naturally experienced by any given species to fully understand the potential impact of ocean acidification.

Research on global changes needs to focus on species which play dominant structuring roles in ecosystems (e.g. herbivores; habitatforming species; Russell et al., 2012). Sea urchins are excellent candidates. They are important grazers that structure habitats and affect temporal dynamics and ecosystem functions (e.g. through trophic cascades; Sala et al., 1998; Bonaviri et al., 2012; Hereu et al., 2012).

The black Arbacia lixula is a common inhabitant of shallowwater hard grounds throughout the Mediterranean Sea. It is also found on the other side of the Atlantic, but only in the Southern Hemisphere, off the coast of Brazil (Gianguzza and Bonaviri, 2013). It is currently one of the most abundant echinoids in shallow rocky habitats of the southern Mediterranean (Guidetti and Dulčić, 2007). This species has a considerable trophic plasticity, ranging from omnivory to strict carnivory (Wangensteen et al., 2011; Agnetta et al., 2013) and its scraping predatory behaviour can play a dominant role in driving switches between one complex state, dominated by a stratified assemblage of several erect macroalgae, to a simpler one dominated by few encrusting algae: the so-called 'barren ground' (Bonaviri et al., 2011; Wangensteen et al., 2012; Agnetta et al., 2013). New and increasing evidence suggests that on-going warming of the Western Mediterranean results in an environment increasingly favourable for the reproduction and development of A. lixula (Francour et al., 1994; Guidetti and Dulčić, 2007; Gianguzza et al., 2011; Privitera et al., 2011; Lessios et al., 2012; Wangensteen et al., 2012).

Considering the great colonizing potential shown by this species, including the ability to cross trans-oceanic barriers to gene flow (Wangensteen et al., 2012), and the massive potential impact of its grazing on coastal ecosystems, it is critical to evaluate how this potential will be modulated by near-future changes such as ocean warming and acidification. In the Western Mediterranean, the planktotrophic A. lixula larvae occur in the water column between Spring and Autumn and can be exposed to the full range of the temperature natural variation $\left(15-24{ }^{\circ} \mathrm{C}\right.$; Fenaux, 1968; Pedrotti, 1993).

The present study aims to investigate the combined impacts of ocean warming and acidification on the early life-history stages of the sea urchin $A$. lixula. The impact of ocean acidification and warming was tested using a fully crossed design with four temperatures $\left(20,24,26\right.$ and $27^{\circ} \mathrm{C}$ ) and two $\mathrm{pH}$ levels ( $\mathrm{pH}$ NBS 8.2, present average $\mathrm{pH}$ and $\mathrm{pH}_{\mathrm{NBS}} 7.9, \mathrm{pH}$ projected by 2100$)$. The selected temperatures cover the upper part of today and near-future environmental variability. Based on Pörtner and Farrell (2008), we predicted an overall negative impact of $\mathrm{pH}$ on the tested parameters (fertilization, larval survival and developmental rate).

\section{Materials and methods}

\subsection{Animal collection and maintenance}

Adult A. lixula (test diameter of $35-45 \mathrm{~mm}$ ) were collected in a shallow rocky shore $(3-5 \mathrm{~m})$ along the coast of Palermo $\left(38^{\circ} 11^{\prime} 45^{\prime \prime} \mathrm{N}-013^{\circ} 14^{\prime} 58^{\prime \prime} \mathrm{E}\right)$ during the peak reproductive season from May to September 2010 (G. Visconti, unpublished data). Collected animals were brought to the laboratory and were kept prior to the experiment for less than $24 \mathrm{~h}$ in recirculating tanks at constant temperature $\left(20^{\circ} \mathrm{C}\right)$ and $\mathrm{pH}_{\mathrm{NBS}}(8.2)$.

\subsection{Fertilization and larval culture}

To avoid male-female incompatibility and mimic field fertilization success, fertilization was conducted with gametes pooled from multiple males and females. Six females and six males were used. Gonads were dissected and rinsed few times in filtered seawater (FSW; Millipore filter $0.45 \mu \mathrm{m}$ ). Eggs were collected and mixed. Sperm was collected, mixed and kept dry before use. Replicates of $900 \mathrm{ml}$ of mixed eggs dilution (1500 eggs/L) were pre-incubated in experimental FSW for 15 min and then mixed $200 \mu$ of dry sperm (final concentration of $3000 \mathrm{sperm} / \mathrm{mL}$ ) in each replicate for fertilization. During larval culture, there was no food supply and the larvae subsisted on their own reserves.

\subsection{Experimental treatments}

Eight different treatments were tested: 4 temperatures $\left(20^{\circ}\right.$, $\left.24^{\circ}, 26^{\circ}, 27{ }^{\circ} \mathrm{C}\right) \times 2 \mathrm{pH}(8.2$ and 7.9). Each treatment was replicated 6 times. The seawater $\mathrm{pH}$ was adjusted by bubbling $\mathrm{CO}_{2}$ until the target $\mathrm{pH}$ was reached. Cultures were then kept in closed bottles for $2 \mathrm{~d}$ and gently mixed using motor driver paddles. Temperature was maintained using an immersion heater. Temperature and $\mathrm{pH}$ was measured 5 times over the course of the experiment. $\mathrm{pH}$ was measured using a $\mathrm{pH}$ meter (Crison GLP21) calibrated with NBS buffers. The carbonate system speciation ( $p \mathrm{CO} 2, \Omega \mathrm{ca}$ and $\Omega$ ar) was calculated from $\mathrm{pH}_{\mathrm{nbs}}$, temperature, salinity (38) and alkalinity $\left(A_{\mathrm{T}}=2.5 \mathrm{mM}\right.$; Rivaro et al., 2010) using CO2SYS (Lewis and Wallace, 1998) with dissociation constants from the study by Mehrbach et al. (1973) refitted by Dickson and Millero (1987).

\subsection{Measured parameters}

Three $1 \mathrm{ml}$ samples were collected in each replicate (48 cultures) at 4 h, 12 h, 24 h, 36 h and 48 h and fixed with few drops of formaldehyde (10\% in FSW). Eggs, embryos and pluteus larvae were counted in each sample and fertilization success (\%) after $4 \mathrm{~h}$ was calculated for each replicate as the ratio between successful fertilization (embryos with 2-8 cells) and unfertilized eggs. Mortality after $48 \mathrm{~h}$ was calculated for each replicate as:

Mortality $(\%)=100 x[1-($ larval density at 48h/initial density $)]$

For each replicate, the $\%$ of pluteus larvae $(100 \times$ [number of pluteus larvae/number of embryos and larvae]) was calculated at $12 \mathrm{~h}, 24 \mathrm{~h}, 36 \mathrm{~h}$ and $48 \mathrm{~h}$. A limited number of larvae were scored for each replicate and time point $(<50)$ and to improve the power of this parameter, the replicates were merged for each treatment. The dynamic of development was characterized by the inflection point of a Gompertz equation of an asymmetrical growth curve estimated by least-square method from \% of pluteus larvae and time (Krönström et al., 2007). 


\subsection{Statistics}

Each mean value is expressed with its standard error of mean (mean \pm SEM). Two factor model ANOVA was used to test the impact of treatment (fixed, $\mathrm{pH}$ and temperature) on fertilization success and mortality. When relevant, Scheffe's post-hoc test was used to test difference between treatments. The Shapiro-Wilk test (1965) was used to confirm that the data were normally distributed and the Levene test was used to confirm that variances were homogenous. All data were analysed using SAS/STAT software.

\section{Results}

\subsection{Seawater chemistry}

Temperature and $\mathrm{pH}_{\mathrm{nbs}}$ were maintained at the target level over the course of the experiment (Table 1). Significant difference in temperature were maintained between the temperature treatments (ANOVA 3, $F=236.27, p<0.0001$; temperature, $F=3306.79$, $p<0.0001$ ) with no significant differences between nominal $\mathrm{pH}$ $(F=0.02, p=0.88)$ or replicates $(F=0.38, p=0.93)$ within a same nominal temperature. For $\mathrm{pH}$, our treatments were control seawater (nominal $\mathrm{pH}=8.2, \mathrm{pH}_{\mathrm{nbs}}=8.16 \pm 0.01$; $\left.\mathrm{pCO}_{2}=511.00 \pm 8.85 \mu \mathrm{atm}, \Omega_{\mathrm{ca}}=4.77 \pm 0.07, \Omega_{\mathrm{ar}}=3.08 \pm 0.04\right)$ and elevated $\mathrm{pCO}_{2}$ (nominal $\mathrm{pH}=7.9, \mathrm{pH}_{\mathrm{nbs}}=7.90 \pm 0.01$; $\left.\mathrm{pCO}_{2}=1053.41 \pm 34.32 \mu \mathrm{atm}, \Omega_{\mathrm{ca}}=2.91 \pm 0.07, \Omega_{\mathrm{ar}}=1.88 \pm 0.05\right)$. Significant difference in $\mathrm{pH}_{\mathrm{nbs}}$ were maintained between the $\mathrm{pH}$ treatments (ANOVA 3, $F=12.22, p<0.0001$; $\mathrm{pH}, F=255.86$, $p<0.0001$ ) with no significant differences between nominal temperature $(F=0.98, p=0.46)$ or replicates $(F=2.51, p=0.06)$ within a same nominal $\mathrm{pH}$.

\subsection{Impact of $\mathrm{pH}$ and temperature on fertilization success}

Fertilization success of $A$. lixula at $4 \mathrm{~h}$ was high (>85\%) at $20^{\circ} \mathrm{C}$ and decreased with increasing temperature $\left(68 \%\right.$ at $24{ }^{\circ} \mathrm{C}, 55 \%$ at $26{ }^{\circ} \mathrm{C}$ and $<1 \%$ at $27^{\circ} \mathrm{C}$; Fig. 1 ). pH had no significant effect on fertilization success (ANOVA 2, model: $F=14.01, p<0.001$; $\mathrm{pH}$ : $F=0.07, p=0.79$ ) with no interaction with temperature (pHxtemp: $F=0.05, p=0.98)$. Temperature had a significant effect on fertilization success (temp: $F=32.61, p<0.001$ ), $27{ }^{\circ} \mathrm{C}$ ( $<1 \%$ fertilization) being significantly different than all other temperatures (Scheffe's post-hoc test, $p<0.05 ;>50 \%$ fertilization $>50 \%$ fertilization).

\subsection{Impact of $\mathrm{pH}$ and temperature on mortality}

Mortality at $48 \mathrm{~h}$ was highly variable among treatments (between 11 and 100\%; Fig. 2). However, only temperature has a significant effect on mortality (model: $F=5.95, p<0.001$; temp:

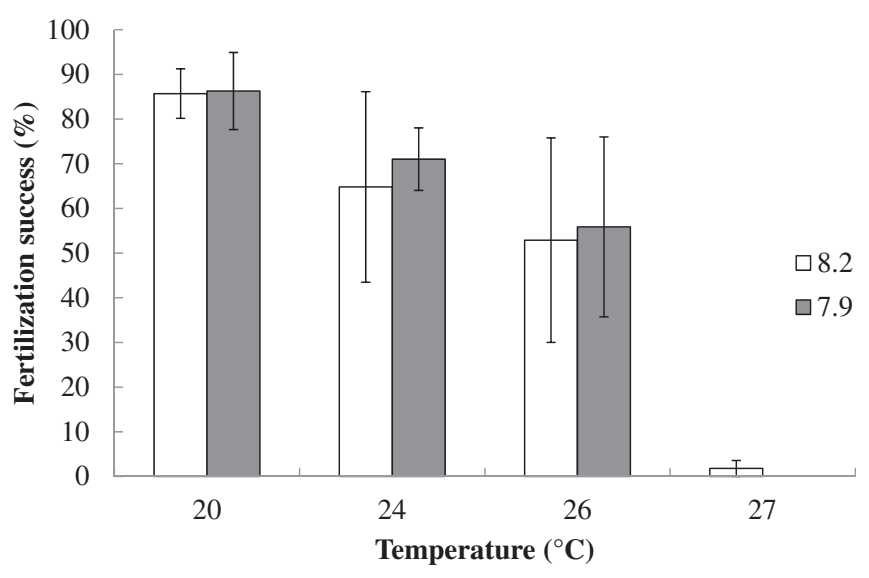

Fig. 1. Impact of $\mathrm{pH}$ and temperature on A. lixula fertilization success at $4 \mathrm{~h}$.

$F=11.18, p<0.001), 27{ }^{\circ} \mathrm{C}$ with $100 \%$ mortality was significantly different from all other temperatures (Scheffe's post-hoc test, $p<0.05$ ). No significant effect of $\mathrm{pH}$ was observed ( $\mathrm{pH}: F=3.72$, $p=0.06$ ) with no interaction with temperature (pHxtemp: $F=1.33$, $p=0.28)$.

\subsection{Impact of $\mathrm{pH}$ and temperature on developmental rate}

The inflexion point (Ip in h) from a Gomperz growth model between time ( $h$ ) and \% of pluteus larvae was calculated as a proxy for developmental rate. At pH 8.2, development to the pluteus stage was faster in warmer temperature (Ip increasing from $19.62 \mathrm{~h}$ at $20^{\circ} \mathrm{C}$ to $11.20 \mathrm{~h}$ at $26^{\circ} \mathrm{C}$; Fig. 3). The $\mathrm{pH}$ effect of developmental rate was dependent of the temperature. At $20^{\circ} \mathrm{C}$, the development was faster at $\mathrm{pH} 7.9$ (Ip = 9.57 h) compared to $\mathrm{pH} 8.2$ (Ip = $19.62 \mathrm{~h}$; Fig. 3A). At $24^{\circ} \mathrm{C}$, the development was similar at both $\mathrm{pH}(\mathrm{Ip}=14 \mathrm{~h}$ at $\mathrm{pH} 8.2$ and $\mathrm{Ip}=12.33$ at $\mathrm{pH} 7.9$; Fig. 3B). At $26^{\circ} \mathrm{C}$, lower $\mathrm{pH}$ had a negative effect on developmental rate leading to a slower development $(\mathrm{Ip}=25.45)$ at $\mathrm{pH} 7.9$ compared to $\mathrm{pH} 8.2(\mathrm{Ip}=11.20$; Fig. 3C). The mortality rate at $27{ }^{\circ} \mathrm{C}$ was $100 \%$ and it was therefore not possible to calculate a developmental rate.

\section{Discussion}

\subsection{Physiological consequences}

4.1.1. Impact of ocean acidification and warming on fertilization

Our results showed that fertilization success in A. lixula measured as the number of cleaving embryos after $4 \mathrm{~h}$ - was robust to both ocean acidification $(\Delta \mathrm{pH}=-0.3)$ and warming for temperature $<27^{\circ} \mathrm{C}$. At higher temperature $\left(27^{\circ} \mathrm{C}\right)$, fertilization success

Table 1

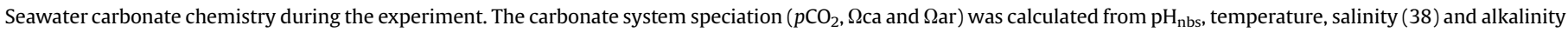
$\left(A_{\mathrm{T}}=2.5 \mathrm{mM}\right.$; Rivaro et al., 2010) using CO2SYS (Lewis and Wallace, 1998).

\begin{tabular}{|c|c|c|c|c|c|c|}
\hline \multicolumn{2}{|l|}{ Nominal } & \multicolumn{2}{|l|}{ Measured } & \multicolumn{3}{|l|}{ Calculated } \\
\hline Temp $\left[{ }^{\circ} \mathrm{C}\right]$ & $\mathrm{pH}$ & Temp $\left[{ }^{\circ} \mathrm{C}\right]$ & $\mathrm{pH}_{\mathrm{nbs}}$ & $p \mathrm{CO}_{2}(\mu \mathrm{atm})$ & $\Omega \mathrm{ca}$ & $\Omega$ ar \\
\hline 20 & 8.2 & $20.35 \pm 0.05$ & $8.16 \pm 0.01$ & $497.96 \pm 16.52$ & $4.34 \pm 0.10$ & $2.77 \pm 0.06$ \\
\hline 20 & 7.9 & $20.25 \pm 0.04$ & $7.89 \pm 0.01$ & $1000.54 \pm 27.33$ & $2.51 \pm 0.06$ & $1.60 \pm 0.04$ \\
\hline 24 & 8.2 & $24.39 \pm 0.04$ & $8.15 \pm 0.01$ & $518.63 \pm 15.11$ & $4.79 \pm 0.10$ & $3.09 \pm 0.06$ \\
\hline 24 & 7.9 & $24.48 \pm 0.07$ & $7.86 \pm 0.02$ & $1166.19 \pm 76.11$ & $2.73 \pm 0.12$ & $1.76 \pm 0.08$ \\
\hline 26 & 8.2 & $26.10 \pm 0.08$ & $8.16 \pm 0.01$ & $509.66 \pm 17.22$ & $5.14 \pm 0.12$ & $3.33 \pm 0.08$ \\
\hline 26 & 7.9 & $26.04 \pm 7.97$ & $7.97 \pm 0.02$ & $895.04 \pm 0.02$ & $3.55 \pm 0.13$ & $2.30 \pm 0.13$ \\
\hline 27 & 8.2 & $26.90 \pm 0.07$ & $8.14 \pm 0.01$ & $544.74 \pm 14.99$ & $4.97 \pm 0.08$ & $3.23 \pm 0.05$ \\
\hline 27 & 7.9 & $27.21 \pm 0.11$ & $7.83 \pm 0.03$ & $1264.36 \pm 87.81$ & $2.77 \pm 0.18$ & $1.80 \pm 0.12$ \\
\hline
\end{tabular}




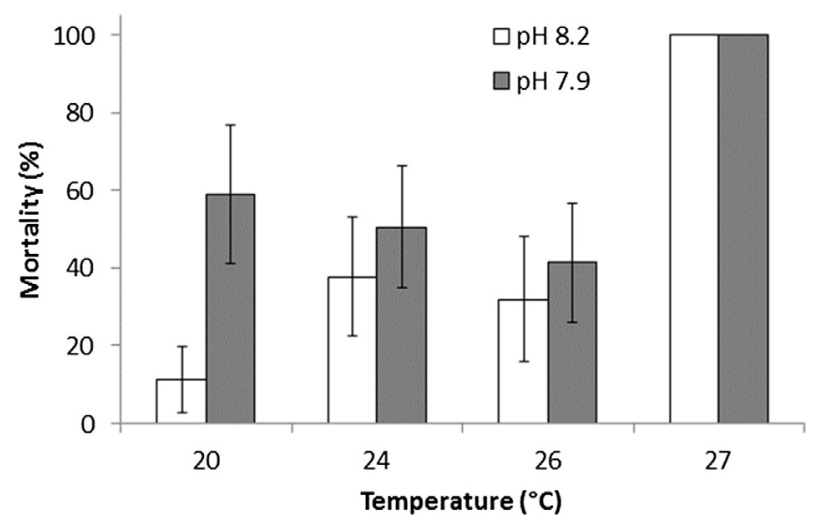

Fig. 2. Impact of pH and temperature on A. lixula mortality 48 h post-fertilization.

was dramatically reduced at less than $1 \%$. The impact of ocean acidification $(\Delta \mathrm{pH}<-0.7)$, alone (11 articles) or in combination with increased temperature (6 articles), on gametes and fertilization was tested on 15 other echinoderm species. In 7 species, ocean
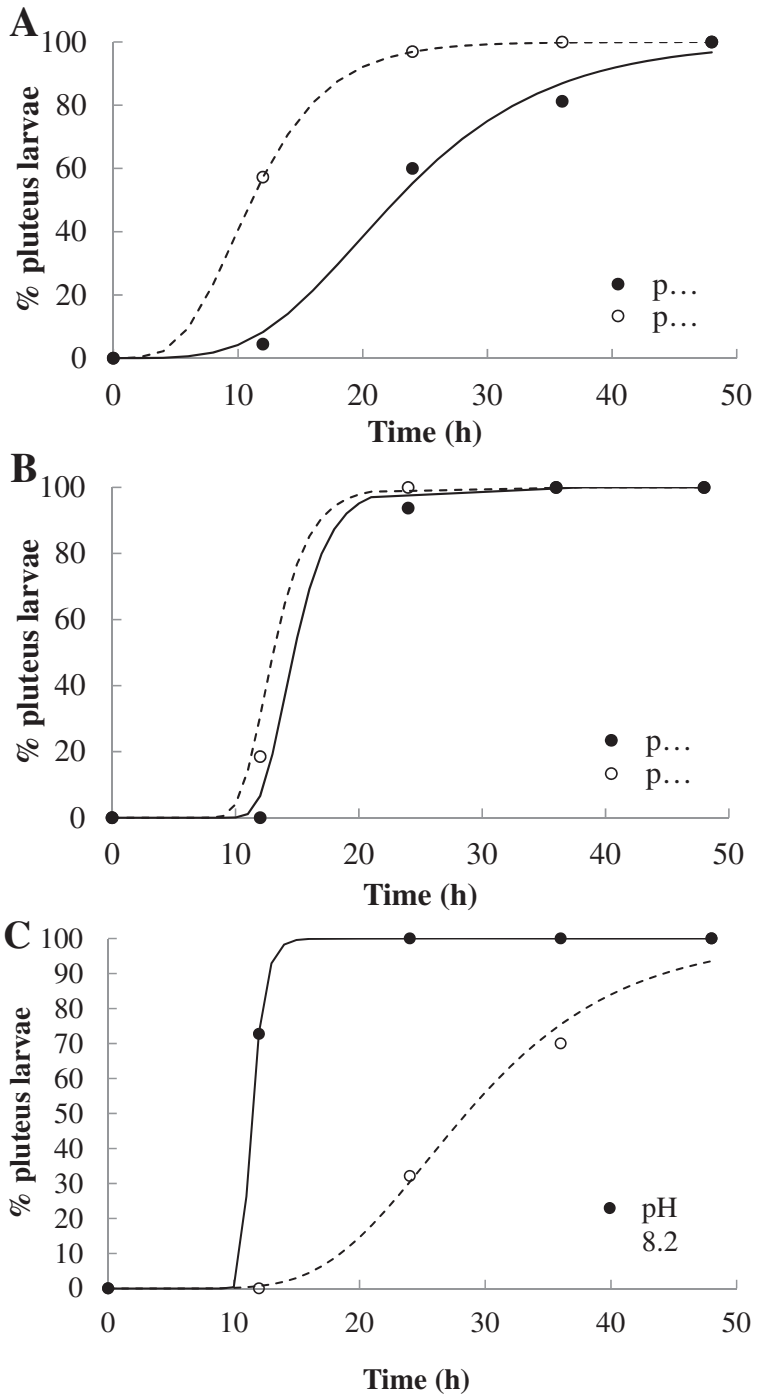

Fig. 3. Impact of $\mathrm{pH}$ on the $\%$ of pluteus larvae through time at 3 different temperature (A, $20^{\circ} \mathrm{C}$; B, $24{ }^{\circ} \mathrm{C}$ and $\mathrm{C}, 26^{\circ} \mathrm{C}$ ). A Gomperz growth model was used to model the relationship between time (d) and \% of pluteus larvae. warming and acidification had no effect of fertilization success (Centrostephanus rodgersii, Byrne et al., 2010b; Echinometra mathaei, Kurihara and Shirayama, 2004; Kurihara et al., 2004; Heliocidaris tuberculata, Byrne et al., 2010b; Hemicentrotus pulcherrimus, Kurihara and Shirayama, 2004; Kurihara et al., 2004; Meridiastra calcar, Nguyen et al., 2012; Patiriella regularis, Byrne et al., 2010b; T. gratilla, Byrne et al., 2010b). Ocean acidification reduced fertilization success in Arachnoides placenta (GonzalezBernat et al., 2012) and Strongylocentrotus franciscanus (Reuter et al., 2011) and in two other species, ocean acidification had no negative effect on fertilization except at low sperm concentration (Odontaster validus, Gonzalez-Bernat et al., 2013) or when combined with increased temperature (Sterechinus neumayeri, Ericson et al., 2010, 2012). Mixed responses from negative to positive were observed in P. lividus (Moulin et al., 2011; Martin et al., 2011) and Heliocidaris erythrogramma. Using similar $\mathrm{pH}$ changes and working on the same species (H. erythrogramma), Byrne et al. (2009; 2010a,b) showed no effect on fertilization while Havenhand et al. (2008) showed a negative effect. This may partly reflect difference in experimental design (polyandry $v s$ single malefemale crosses, sperm concentration, stability of $\mathrm{pH}$, use of different sperm:egg ratio, sperm-egg contact time etc.; e.g. Reuter et al., 2011) but also individual variability in reproductive success (Schlegel et al., 2012). Our results which showed no effect of ocean acidification on fertilization success were then consistent with most of the published data. However, we only considered a high sperm-egg ratio (2000:1) and long sperm-egg contact time and our results may underestimate this impact. Extreme temperature $\left(27{ }^{\circ} \mathrm{C}\right)$ was inhibiting fertilization $(<1 \%)$. A similar impact was observed in $H$. erythrogramma (Byrne et al., 2009). As a consequence, $A$. lixula fertilization might be sufficiently resilient to nearfuture ocean warming and acidification although it should be impaired during extreme warming events. Such results emphasise the pressing need to identify approaches that can rapidly assess the degree of stress experienced by populations, integrate the effects of multiple stressors and predict the likely outcome for population persistence (Sokolova et al., 2012; Sarà et al., 2012).

\subsubsection{Impact of ocean acidification and warming on larval survival}

In the majority of tested species ( 9 out of 13), ocean acidification had no effect on larval survival (see Dupont and Thorndyke, 2013 for review). In the other 4 species, the impact was an increased mortality (Arachnoides placenta, Gonzalez-Bernat et al., 2012; Odontaster validus, Gonzalez-Bernat et al., 2013; Patiriella regularis, Byrne et al., 2013) with a 100\% mortality within 7 days observed in the brittlestar Ophiothrix fragilis (Dupont et al., 2008). Our results showed that ocean acidification, alone or in combination with elevated temperature $\left(<27^{\circ} \mathrm{C}\right)$ do not increase the larval mortality. At the highest temperature $\left(27^{\circ} \mathrm{C}\right)$, all larvae experienced increased mortality, dying in only 3d. Present result is consistent with that observed in the larval sea star Patiriella regularis (Byrne et al., 2013) and it represents a further support on the fact that the temperature is the main factor limiting fertilization and larvae survival as recently showed by many studies on thermal tolerance limits of marine ectotherms (Kooijman, 2010 for review). In our experimental species, larvae were subjected to an evident physiological tipping point around $27^{\circ} \mathrm{C}$. Such a result mirrored the physiological tolerance limits of $A$. lixula larvae resembling the western Mediterranean pelagic thermal habitat where it lives. Temperature of water masses of the first infralittoral zone (from subsurface to the first thermocline at about $10-13 \mathrm{~m}$ ) is on average indeed around 24-26.5 ${ }^{\circ} \mathrm{C}$ in Southern MED, rarely exceeding the $27^{\circ} \mathrm{C}$ unless for a few hours during warmer days. A. lixula larvae could moreover live very close to the edge of their metabolic machinery functioning (Sarà et al., 2011). As a consequence, warming in a context of 
climate change or heating waves (e.g. Garrabou et al., 2009) may lead to mass mortalities of sea-urchin's larval reservoir as shown for other benthic organisms (Cerrano et al., 2000).

\subsubsection{Impact of ocean acidification and warming on larval growth}

Growth rate is a more sensitive endpoint to environmental changes and one of the most documented effects of ocean acidification on larval stages is a delay in development. For example 16 out of the 19 tested species of echinoderm's larvae showed a delay in development when raised in ocean acidification conditions (see Dupont and Thorndyke, 2013 for review). Temperature has a very well described positive effect on growth rate up to the optimum growth rate while extreme increasing temperatures induce delay in development (Duarte, 2007). Only 3 studies studied the combination between warming and acidification on echinoderm larvae. In seastar Meridiastra calcar larval growth rate decreased while temperature increased although there was not any effect from acidification treatment (Nguyen et al., 2012). Based on the theoretical framework developed by Pörtner and Farrell (2008) it was predicted that (i) response to ocean acidification is modulated by temperature and, (ii) ocean acidification can only drive negative response in animals. For example, it is predicted that warming can increase resilience to ocean acidification on the cold side of a species optimal temperature, but enhances sensitivity when a species experiences both drivers close to its upper limits of thermal tolerance. This is supported by most of the work published on the impact of ocean acidification on echinoderm larvae with two noticeable exceptions as follows: (i) $\mathrm{a}+3{ }^{\circ} \mathrm{C}$ warming minimized the negative effect of acidification on larval growth in the larvae of the sea urchin T. gratilla (Sheppard Brennand et al., 2010) and (ii) larval stages of the sea star Crossaster papposus increased their growth when exposed to ocean acidification (Dupont et al., 2010b). Our results challenged the hypothesis that ocean acidification can only have a negative impact on larval development. Indeed, temperature modulates the impact of decreasing $\mathrm{pH}$ on the developmental rate with a positive effect (faster growth) under ocean acidification conditions at $20{ }^{\circ} \mathrm{C}$, a neutral effect at $24{ }^{\circ} \mathrm{C}$ and a negative effect (slower growth) at $26^{\circ} \mathrm{C}$. This apparent paradox can be solved thanks to a good mechanistic understanding of the impact of both temperature and ocean acidification on larval physiology and energy budget (Fig. 4). Both increased temperature (e.g. Peck and Prothero-Thomas, 2002) and pH (Stumpp et al., 2011, 2012) induce an up-regulation of larval metabolism. An increased metabolism under non-limiting energy conditions can translate into an increased scope for growth. This explains the welldocumented positive effect of temperature on growth rates since temperature often leads to an increased metabolism and an increase in food uptake (e.g. Podolsky and Emlet, 1993). This can also

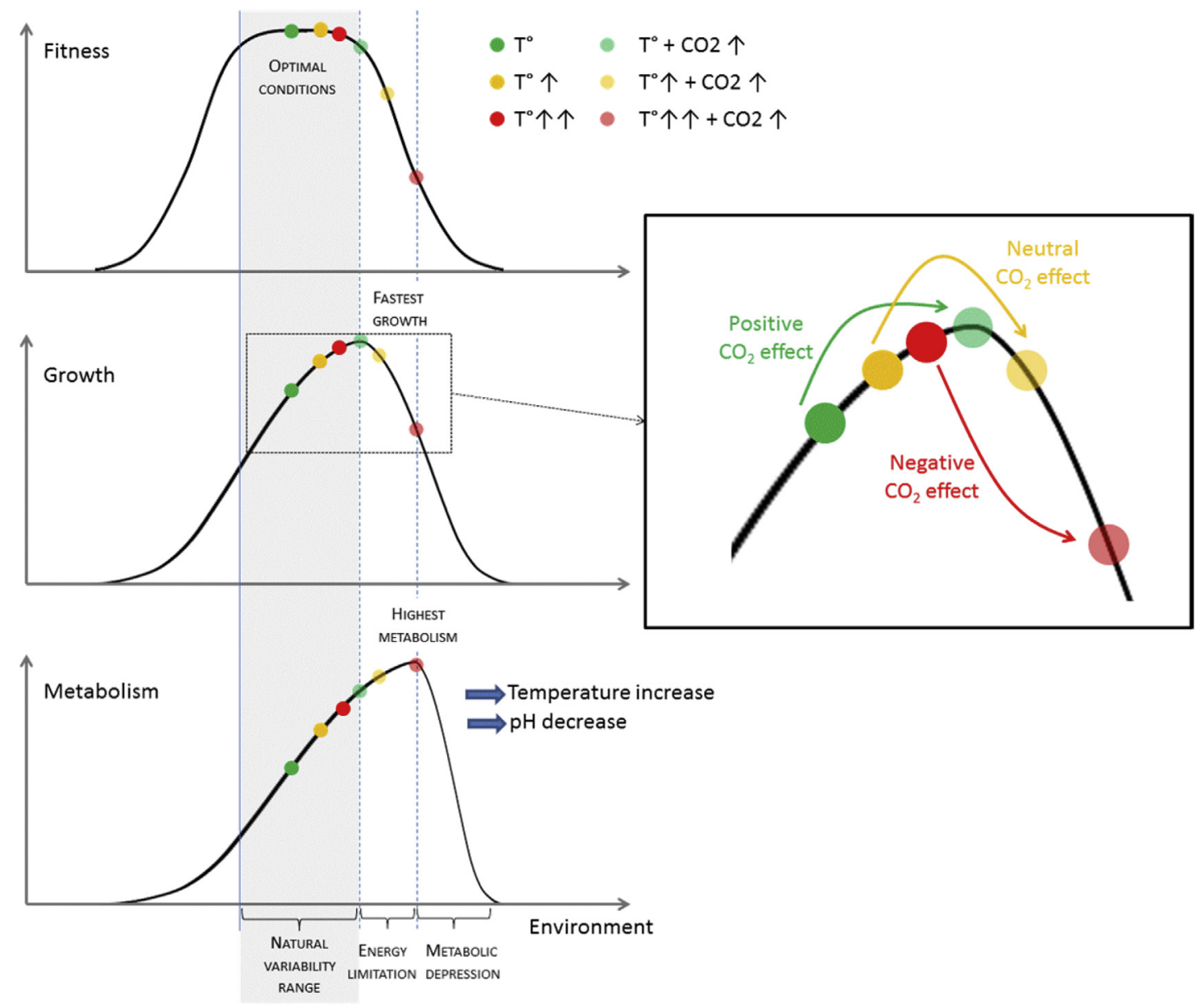

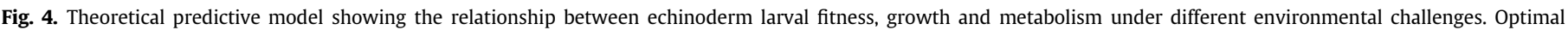

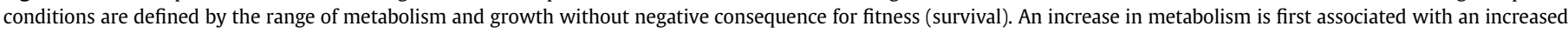

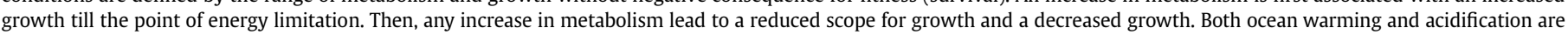

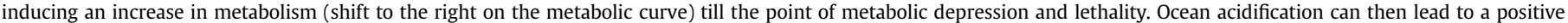

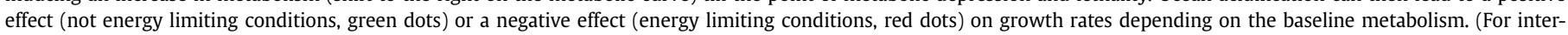
pretation of the references to colour in this figure legend, the reader is referred to the web version of this article.) 
explain the positive effect of ocean acidification on the larvae of the sea star Crossaster papposus (Dupont et al., 2010a,b,c). It was hypothesized that the lecithotrophic life-history strategy (production of few energy rich eggs) allowed an increased growth following an increased in metabolism. On the other hand, under limiting energy conditions, an increased metabolism is associated with a reduced scope for growth as demonstrated in sea urchin larvae exposed to ocean acidification conditions (Stumpp et al., 2011). We can also hypothesize that under extreme stress, larvae are unable to compensate for the environmental challenge through increased metabolism and experience metabolic depression (Pörtner and Farrell, 2008). In theory, different combinations of increased temperature and $\mathrm{pH}$ can then lead to different sublethal biological responses. (i) If the baseline metabolism is far from its optimal (e.g. $\mathrm{pH} 8.2 / 20{ }^{\circ} \mathrm{C}$ in our experiment), the larvae is not energy limited and an increase in metabolism (e.g. increased temperature or decreased $\mathrm{pH}$ ) can lead to an increased growth rate; (ii) If the baseline metabolism is closer to its optimal (e.g. pH 8.2/26 ${ }^{\circ} \mathrm{C}$ ), any increase in metabolism will lead to a reduced scope for growth and lead to a decreased growth rate. Under extreme chronic metabolic stress (e.g. $27^{\circ} \mathrm{C}$ ), the effect is lethal. This new model needs to be tested but any large scale prediction of the combined impact of ocean warming and acidification would require to better understand the relative contribution of temperature, $\mathrm{pH}$ and any other modulating factors (e.g. food, Marsh and Manahan, 1999) on the metabolism of marine species (Kooijman, 2010).

\subsection{Ecological consequences}

A. lixula and its sister species Arbacia punctulata have been the object of intensive investigations in cell biology, biochemistry of fertilization and early development (e.g. Harding and Harding, 1952; Castagna et al., 1981; George et al., 1990; De Giorgi et al., 1991). Recently, renewed interest in this species arose mainly due to its ecological role, its unusually wide distribution area (from equatorial waters to temperate Mediterranean) and its warm-water affinity (Gianguzza et al., 2011; Wangensteen et al., 2012; Privitera et al., 2011; Agnetta et al., 2013).

A study on its phylogeography and population genetics corroborates the Stefanini (1911) hypothesis (backed by the lack of its fossil record in Mediterranean) that A. lixula is not a native species but a thermophilous colonizer, probably originated at tropical Atlantic region, which spread throughout the Mediterranean during the last interglacial period of the Pleistocene (Wangensteen et al., 2012). In this period, the minimum winter surface temperatures of the Mediterranean Sea had been warmer than $19{ }^{\circ} \mathrm{C}$ and this could have led larvae of the tropical Atlantic population of A. lixula to cross the Strait of Gibraltar and colonize the Northern Mediterranean. Furthermore, the authors suggested that the current population expansion of $A$. lixula in Mediterranean could be due to increased larval success driven by the ongoing climate warming.

It is well known that one direct consequence of warming is a simultaneous increase in the abundance of thermo-tolerant species and the disappearance or rarefaction of 'cold' stenothermal species (CIESM, 2008). From a study on climate warming and the range extension of thermophilic sea urchin species, a significant positive relationship between $C$. rodgersii density and increased ocean temperatures has been unequivocally proven in eastern Tasmania (Ling et al., 2008). Hart and Scheibling (1988) report evidence of an analogous temperature threshold mechanism for Strongylocentrotus droebachiensis along the Atlantic coast of Nova Scotia where sea urchin population booms and associated were correlated with a positive ocean temperature anomaly allowing optimal temperatures for larval development.
To date, few studies were focused on the impact of ocean acidification on Arbacia spp. development. The sub-Antarctic species Arbacia dufresni experienced a delay in development when raised at low pH with no effect on survival (Catarino et al., 2012b). Carr et al. (2006) showed that pH tolerance limits for the fertilization and embryological development (2 days) of $A$. punctulata were 6.9-8.8.

According to our data, it is likely that recent and future warming of the Western Mediterranean can result in an environment increasingly favourable for the reproduction and development of a thermotolerant species such as A. lixula (Privitera et al., 2011). We undoubtedly show that both fertilization and early larval development, using gamete from $A$. lixula adults acclimatized at $20^{\circ} \mathrm{C}$, were thermotolerant to $26^{\circ}\left(+6^{\circ} \mathrm{C}\right.$ above sea surface temperature SST). Developmental rate was 1.7 times faster at $26^{\circ} \mathrm{C}$ compared to $20{ }^{\circ} \mathrm{C}$ with no negative consequences on fertilization rate and survival. This also indicates that $A$. lixula may be in sub-optimal conditions in the Mediterranean and may then benefit from future ocean warming. Ocean acidification has a negative effect at the higher temperature $\left(26^{\circ} \mathrm{C}\right)$ showing that it may constrain the positive effect of warming. In the future ocean, larvae of the $A$. lixula may experience short-term exposure to these more challenging temperatures $\left(>24{ }^{\circ} \mathrm{C}\right)$ with unknown consequences for their fitness. It is then difficult to make any prediction on the combined impact of ocean warming and acidification but it seems likely that on the short term, A. lixula can benefit from the positive effect of both warming and acidification on their larval growth rate and then experience a higher survival rate through decreased predation (Dupont et al., 2010c).

Calosi et al. (2013) showed that density of adult A. lixula was significantly greater than $P$. lividus in elevated $\mathrm{PCO}_{2} /$ low $\mathrm{pH}$ conditions. This pattern could be due to the relatively superior ability of A. lixula to regulate its extracellular fluid under elevated $\mathrm{pCO}_{2}$ (Calosi et al., 2013).

If $A$. lixula increases its densities in the foreseeable future, it could have serious consequences for the Mediterranean ecosystem diversity and functioning. Many authors support the increasing evidence that $A$. lixula, less prone to predation than $P$. lividus, may establish a positive feedback which tends to stabilize and maintain the barren grounds in rocky littoral ecosystems (Bonaviri et al., 2011). Despite its ecological importance, no information was available on the impact of ocean acidification on A. lixula.

More research is needed to fully investigate the combined impacts of ocean acidification and warming on A. lixula including long-term exposure (including subsequent life-history stages, e.g. Dupont et al., 2012) allowing estimating acclimation and adaptation potential, the modulating role of ecological interactions and other environmental parameters (Kroeker et al., 2013). Future research should also aim at the investigation of the effects of multiple stressors on sea urchin recruitment and adult survival. This would allow obtaining the objective and completing the understanding of sea urchin population dynamic and potentially resultant effects on benthic community, in relation with global changes.

\section{Acknowledgements}

The authors are indebted to Dr. Manuela Butera for her indispensable help during lab work, Eleanor Butler for revising the English text and to two anonymous reviewer for their helpful comments on the first drafts of the manuscript. Experiments described in this paper comply with Italian current laws. This study was funded by the M.A.T.T.M. (Ministero dell'Ambiente Difesa del Territorio e del Mare) research project "Monitoraggio ciclo riproduttivo di Paracentrotus lividus e Arbacia lixula nell'AMP Capo 
Gallo Isola delle Femmine" and by the Linnaeus Centre for Marine Evolutionary Biology at the University of Gothenburg (http://www. cemeb.science.gu.se/). A Linnaeus-grant from the Swedish Research Councils VR and Formas supported this study.

\section{References}

Agnetta, D., Bonaviri, C., Badalamenti, F., Scianna, C., Vizzini, S., Gianguzza, P., 2013. Functional traits of two co-occurring sea urchins across a barren/forest patch system. Journal of Sea Research 76, 170-177.

Bonaviri, C., Pipitone, C., Gianguzza, P., Hereu, B., 2012. Micropredation on sea urchins as a potential stabilizing process for rocky reefs. Journal of Sea Research $73,18-23$.

Bonaviri, C., Vega Fernández, T., Fanelli, G., Badalamenti, F., Gianguzza, P., 2011. Leading role of sea urchin Arbacia lixula in maintaining barren state in southwestern Mediterranean. Marine Biology 158, 2505-2513.

Byrne, M., Gonzalez-Bernat, M., Doo, S., Foo, S., Soars, N., Lamare, M., 2013. Effects of ocean warming and acidification on embryos and non-calcifying larvae of the invasive sea star Patiriella regularis. Marine Ecology Progress Series 473, 235246.

Byrne, M., 2011. Impact of ocean warming and ocean acidification on marine invertebrate life history stages. Oceanography and Marine Biology An Annual Review 49, 1-42. Edited by J. D. M. Gordon CRC Press.

Byrne, M., Soars, N., Selvakumaraswamy, P., Dworjanyn, S.A., Davis, A.R., 2010a. Sea urchin fertilization in a warm, acidified and high $\mathrm{pCO}_{2}$ ocean across a range of sperm densities. Marine Environmental Research 69, 234-239.

Byrne, M., Soars, N.A., Ho, M.A., Wong, E., McElroy, D., Selvakumaraswamy, P. Dworjanyn, S.A., Davis, A.R., 2010b. Fertilization in a suite of coastal marine invertebrates from SE Australia is robust to near-future ocean warming and acidification. Marine Biology 157, 2061-2069.

Byrne, M., Ho, M., Selvakumaraswamy, P., Nguyen, H.D., Dworjanyn, S.A., Davis, A.R. 2009. Temperature, but not $\mathrm{pH}$, compromises sea urchin fertilization and early development under near-future climate change scenarios. Proceedings of the Royal Society B 276, 1883-1888.

Caldeira, K., Wickett, M.E., 2003. Anthropogenic carbon and ocean pH. Nature 425 365.

Caldwell, G.S., Fitzer, S., Gillespie, C.S., Pickavance, G., Turnbull, E., Bentley, M.G., 2011. Ocean acidification takes sperm back in time. Invertebrate Reproduction and Development 55, 217-221.

Calosi, P., Rastrick, S.P.S., Graziano, M., Thomas, S.C., Baggini, C., Carter, H.A., HallSpencer, J.M., Milazzo, M., Spicer, J.I., 2013. Distribution of sea urchins living near shallow water $\mathrm{CO}_{2}$ vents is dependent upon species acid-base and ionregulatory abilities. Marine Pollution Bulletin, 1-15. http://dx.doi.org/10.1016/ j.marpolbul.2012.11.040.

Carr, R.S., Biedenbach, J.M., Nipper, M., 2006. Influence of potentially confounding factors on sea urchin porewater toxicity tests. Archives of Environmental Contamination and Toxicology 51, 573-579.

Castagna, C., Sinatra, F., Scalia, M., Capodicasa, V., 1981. Observations of the effect of zinc on the gametes and various development phases of Arbacia lixula. Marine Biology 64, 285-289.

Catarino, A.I., Bauwens, M., Dubois, P., 2012a. Acid-base balance and metabolic response of the sea urchin Paracentrotus lividus to different seawater $\mathrm{pH}$ and temperatures. Environmental Science and Pollution Research. http://dx.doi.org/ 10.1007/s11356-012-0743-1.

Catarino, A.I., De Ridder, C., Gonzalez, M., Gallardo, P., Dubois, P., 2012b. Sea urchin Arbacia dufresnei (Blainville 1825) larvae response to ocean acidification. Polar Biology 35, 455-461.

Cerrano, C., Bavestrello, G., Bianchi, C.N., Cattaneo-Vietti, R., Bava, S., Morganti, C., Morri, C., Picco, P., Sara, G., Schiaparelli, S., Siccardi, A., Sponga, F., Siccardi, A., 2000. A catastrophic mass-mortality episode of gorgonians and other organisms in the Ligurian Sea (North-western Mediterranean), summer 1999. Ecology Letters 3, 284-293.

CIESM, 2008. Climate warming and related changes in Mediterranean marine biota, $\mathrm{N}^{\circ}$ 35. In: Briand, F. (Ed.), CIESM Workshop Monographs, Monaco.

De Giorgi, C., De Luca, F., Saccone, C., 1991. Mitochondrial DNA in the sea urchin Arbacia lixula: nucleotide sequence differences between two polymorphic molecules indicate asymmetry of mutations. Gene 103, 249-252.

Dickson, A.G., Millero, F.J., 1987. A comparison of the equilibrium constants for the dissociation of carbonic acid in seawater media. Deep Sea Research 34, 1733 1743.

Duarte, C.M., 2007. Marine ecology warms up to theory. Trends in Ecology and Evolution 22, 331-333.

Dupont, S., Havenhand, J., Thorndyke, W., Peck, L., Thorndyke, M., 2008. Near-future level of $\mathrm{CO}_{2}$-driven ocean acidification radically affects larval survival and development in the brittlestar Ophiothrix fragilis. Marine Ecology Progress Series 373, 285-294.

Dupont, S., Thorndyke, M., 2013. Direct impacts of near-future ocean acidification on sea urchins. In: Climate Change Perspectives from the Atlantic: Past, Present and Future.

Dupont, S., Ortega-Martınez, O., Thorndyke, M., 2010a. Impact of near-future ocean acidification on echinoderms. Ecotoxicology 19, 449-462.

Dupont, S., Lundve, B., Thorndyke, M., 2010b. Near future ocean acidification increases growth rate of the lecithotrophic larvae and juveniles of the sea star
Crossaster papposus. Journal of Experimental Zoology Part B: Molecular and Developmental Evolution 314 B, 382-389.

Dupont, S., Dorey, N., Thorndyke, M., 2010c. What meta-analysis can tell us on vulnerability of marine biodiversity to ocean acidification? Estuarine, Coastal and Shelf Science 89, 182-185.

Ericson, J.A., Ho, M.A., Miskelly, A., King, C.K., Virtue, P., Tilbrook, B., Byrne, M., 2012 Combined effects of two ocean change stressors, warming and acidification, on fertilization and early development of the Antarctic echinoid Sterechinus neumayeri. Polar Biology 35, 1027-1034.

Ericson, J.A., Lamare, M.D., Morley, S.A., Barker, M.F., 2010. The response of two ecologically important Antarctic invertebrates (Sterechinus neumayeri and Parborlasia corrugatus) to reduced seawater $\mathrm{pH}$ : effects on fertilisation and embryonic development. Marine Biology 157, 2689-2702.

Fabry, V.J., Seibel, B.A., Feely, R.A., Orr, J.C., 2008. Impacts of ocean acidification on marine fauna and ecosystem processes. ICES Journal of Marine Science 65 414-432.

Fenaux, L., 1968. Maturation des gonades et cycle saisonnier des larves chez A. lixula, P.lividus et P. microtuberculatus à Villefranche- Sur-Mer. Vie Milieu Serie A $19,1-52$

Foo, S.A., Dworjanyn, S.A., Poore, A.G.B., Byrne, M., 2012. Adaptive capacity of the habitat modifying sea urchin Centrostephanus rodgersii to ocean warming and ocean acidification: performance of early embryos. PLoS ONE 7, e42497.

Francour, P., Boudouresque, C.F., Harmelin, J.G., Harmelin-Vivien, M.L., Quignard, J.P., 1994. Are the Mediterranean waters becoming warmer? information from biological indicators. Marine Pollution Bulletin 28, 523-526.

Garrabou, J., Coma, R., Bensoussan, N., Bally, M., Chevaldonné, P., Cigliano, M. Diaz, D., Harmelin, J.G., Gambi, M.C., Kersting, D.K., Ledoux, J.B., Lejeusne, C. Linares, C., Marschal, C., Pérez, T., Ribes, M., Romano, J.C., Serrano, E., Teixido, N., Torrents, O., Zabala, M., Zuberer, F., Cerrano, C., 2009. Mass mortality in Northwestern Mediterranean rocky benthic communities: effects of the 2003 heat wave. Global Change Biology 15, 1090-1103.

George, S.B., Cellario, C., Fenaux, L., 1990. Population differences in egg quality of Arbacia lixula (Echinodermata: Echinoidea): proximate composition of eggs and larval development. Journal of Experimental Marine Biology and Ecology 141, 107-118.

Gianguzza, P., Agnetta, D., Bonaviri, C., Di Trapani, F., Visconti, G., Gianguzza, F. Riggio, S., 2011. The rise of thermophilic sea urchins and the expansion of barren grounds in the Mediterranean Sea. Chemistry and Ecology 27, 129-134.

Gianguzza, P., Bonaviri, C., 2013. Arbacia. Developments in Aquaculture and Fisheries Science 38, 275-283.

Gonzalez-Bernat, M.J., Lamare, M., Barker, M., 2013. Effects of reduced seawater pH on fertilisation, embryogenesis and larval development in the Antarctic seastar Odontaster validus. Polar Biology 36, 235-247.

Gonzalez-Bernat, M.J., Lamare, M., Uthicke, S., Byrne, M., 2012. Fertilization, embryogenesis and larval development in the tropical intertidal sand dollar Arachnoides placenta in response to reduced seawater pH. Marine Biology http://dx.doi.org/10.1007/s00227-012-2034-2.

Guidetti, P. Dulčić, J., 2007. Relationship among predatory fish, sea urchins and barrens in Mediterranean rocky reefs across a latitudinal gradient. Marine Environmental Research 63, 168-184.

Harding, C.V., Harding, D., 1952. Cross fertilization with the sperm of Arbacia lixula. Experimental Cell Research 3, 475-484.

Hart, M.W., Scheibling, R.E., 1988. Heat waves, baby booms, and the destruction of kelp beds by sea urchins. Marine Biology 99, 167-176.

Havenhand, J.N., Butler, F.R., Thorndyke, M.C., Williamson, J.E., 2008. Near-future levels of ocean acidification reduce fertilization success in a sea urchin. Current Biology 18, 651-652.

Hereu, B., Linares, C., Sala, E., Garrabou, J., Garcia-Rubies, A., Diaz, D., Zabala, M. 2012. Multiple processes regulate long-term population dynamics of sea urchins on Mediterranean rocky reefs. PLoS ONE 7 art. no. e36901.

IPCC (Intergovernmental Panel on Climate Change), 2007. The Fourth Assessment Report of the IPCC. Cambridge University Press, Cambridge, UK.

Kooijman, S.A.L.M., 2010. Dynamic Energy Budget Theory for Metabolic Organization. Cambridge University Press, Cambridge, UK.

Kroeker, K.J., Micheli, F., Gambi, M.C., 2013. Ocean acidification causes ecosystem shifts via altered competitive interactions. Nature Climate Change 3, 156159.

Krönström, J., Dupont, S., Mallefet, J., Thorndyke, M., Holmgren, S., 2007. Serotonin and nitric oxide interaction in the control of bioluminescence in northern krill, Meganyctiphanes norvegica (M. Sars). Journal of Experimental Biology 209, 3179-3187.

Kurihara, $\mathrm{H}$., Shirayama, Y., 2004. Effects of increased atmospheric $\mathrm{CO}_{2}$ on sea urchin early development. Marine Ecology Progress Series 274, 161-169.

Kurihara, H., Shimode, S., Shirayama, Y., 2004. Sub-lethal effects of elevated concentration of $\mathrm{CO}_{2}$ on planktonic copepods and sea urchins. Journal of Oceanography $60,743-750$.

Lessios, H.A., Lockhart, S., Collin, R., Sotil, G., Sánchez-Jérez, P., Zigler, K.S., Perez, A.F. Garrido, M.J., Geyer, L.B., Bernardi, G., Vacquier, V.D., Haroun, R., Kessing, B.D. 2012. Phylogeography and bindin evolution in Arbacia, a sea urchin genus with an unusual distribution. Molecular Ecology 21, 130-144.

Lewis, E., Wallace, D.W.R., 1998. $\mathrm{CO}_{2} \mathrm{SYS}$-Program Developed for the $\mathrm{CO}_{2}$ System Calculations. Carbon Dioxide Inf Anal Center Report ORNL/CDIAC-105.

Ling, S.D., Johnson, C.R., Frusher, S., King, C.K., 2008. Reproductive potential of a marine ecosystem engineer at the edge of a newly expanded range. Global Change Biology 14, 907-915. 
Marsh, A.G., Manahan, D.T., 1999. A method for accurate measurements of the respiration rates of marine invertebrate embryos and larvae. Marine Ecolology Progress Series 184, 1-10.

Martin, S., Richier, S., Pedrotti, M.L., Dupont, S., Castejon, C., Gerakis, Y., Kerros, M.E. Oberhänsli, F., Teyssié, J.L., Jeffree, R., Gattuso, J.P., 2011. Early development and molecular plasticity in the Mediterranean sea urchin Paracentrotus lividus exposed to $\mathrm{CO}_{2}$-driven acidification. Journal of Experimental Biology 214, 13571368.

Mehrbach, C., Culberson, C.H., Hawley, J.E., Pytkowicz, R.M., 1973. Measurement of the apparent dissociation constants of carbonic acid in seawater at atmospheric pressure. Limnology and Oceanography 18, 897-907.

Moulin, L., Catarino, A.I., Claessens, T., Dubois, P., 2011. Effects of seawater acidification on early development of the intertidal sea urchin Paracentrotus lividus (Lamarck 1816). Marine Pollution Bulletin 62, 48-54.

Nguyen, H.D., Doo, S.S., Soars, N.A., Byrne, M., 2012. Noncalcifying larvae in a changing ocean: warming, not acidification/hypercapnia, is the dominant stressor on development of the sea star Meridiastra calcar. Global Change Biology 18, 2466-2476.

Peck, L.S., Prothero-Thomas, E., 2002. Temperature effects on the metabolism of larvae of the Antarctic starfish Odontaster validus, using a novel microrespirometry method. Marine Biology 141, 271-276.

Pedrotti, M.L., 1993. Spatial and temporal distribution and recruitment of echinoderm larvae in the Ligurian Sea. Journal Marine Biological Association UK 73, 513-530.

Podolsky, R., Emlet, R.B., 1993. Partitioning the effects of temperature and viscosity on swimming and water movement by sand dollar larvae (Dendraster excentricus). Journal of Experimental Biology 176, 207-221.

Pörtner, H.O., Farrell, A.P., 2008. Physiology and climate change. Science 322, 690692.

Privitera, D., Noli, M., Falugi, C., Chiantore, M., 2011. Benthic assemblages and temperature effects on Paracentrotus lividus and Arbacia lixula larvae and settlement. Journal of Experimental Marine Biology and Ecology 407, 6-11.

Reuter, K.E., Lotterhos, K.E., Crim, R.N., Thompson, C.A., Harley, C.D.G., 2011. Elevated $\mathrm{pCO}_{2}$ increases sperm limitation and risk of polyspermy in the red sea urchin Strongylocentrous franciscanus. Global Change Biology 17, 163-171.

Rivaro, P., Messa, R., Massolo, S., Frache, R., 2010. Distributions of carbonate properties along the water column in the Mediterranean Sea: spatial and temporal variations. Marine Chemistry 121, 236-245.

Russell, B.D., Harley, C.D.G., Wernberg, T., Mieszkowska, N., Widdicombe, S., HallSpencer, J.M., Connell, S.D., 2012. Predicting ecosystem shifts requires new approaches that integrate the effects of climate change across entire systems. Biology Letters 8, 164-166.
Sala, E., Boudouresque, C.F., Harmelin-Vivien, M., 1998. Fishing, trophic cascades, and the structure of algal assemblages: evaluation of an old but untested paradigm. Oikos 82, 425-439.

Sarà, G., Milanese, M., Prusina, I., Sarà, A., Angel, D.L., Glamuzina, B., Nitzan, T., Freeman, S., Rinaldi, A., Palmeri, V., Montalto, V., Lo Martire, M., Gianguzza, P., Arizza, V., Lo Brutto, S., De Pirro, M. Helmuth, B., Murray, J., De Cantis, S. Williams, G.A., 2012. The impact of climate change on Mediterranean intertidal communities: losses in coastal ecosystem integrity and services. Regional Environmental Change. http://dx.doi.org/10.1007/s10113-012-0360-z (in press).

Sarà, G., Kearney, M., Helmuth, B., 2011. Combining heat-transfer and energy budget models to predict local and geographic patterns of mortality in Mediterranean intertidal mussels. Chemistry and Ecology 27, 135-145.

Schlegel, P., Havenhand, J.N., Gillings, M.R., Williamson, J.E., 2012. Individual variability in reproductive success determines winners and losers under ocean acidification: a case study with sea urchins. PLoS ONE 7 art. no. e53118.

Shapiro, S.S., Wilk, M.B., 1965. An analysis of variance test for normality (complete samples). Biometrika 52, 591-611.

Sheppard Brennand, H., Soars, N., Dworjanyn, S.A., Davis, A.R., Byrne, M., 2010. Impact of ocean warming and ocean acidification on larval development and calcification in the sea urchin Tripneustes gratilla. PLoS ONE 5, e11372.

Sokolova, I.M., Frederich, M., Bagwe, R., Lannig, G., Sukhotin, A.A., 2012. Energy homeostasis as an integrative tool for assessing limits of environmental stress tolerance in aquatic invertebrates. Marine Environmental Research 79,1-15.

Stefanini, G., 1911. Di alcune Arbacia fossili. Rivista Italiana di Paleontologia 17, $51-52$.

Stumpp, M., Hu, M.Y., Melzner, F., Gutowska, M.A., Dorey, N., Himmerkus, N., Holtmann, W.C., Dupont, S.T. Thorndyke, M.C., Bleich, M., 2012. Towards improved socio-economic assessments of ocean acidification's impacts. Proceedings of the National Academy of Sciences of the United States of America 109, 18192-18197.

Stumpp, M., Wren, J., Melzner, Frank, Thorndyke, Mike, Dupont, S., 2011. CO induced seawater acidification impacts sea urchin larval development I: elevated metabolic rates decrease scope for growth and induce developmental delay. Comparative Biochemistry and Physiology A-molecular \& Integrative Physiology 160, 331-340.

Wangensteen, O.S., Turon, X., García-Cisneros, A., Recasens, M., Romero, J., Palacín, C., 2011. A wolf in sheep's clothing: carnivory in dominant sea urchins in the Mediterranean. Marine Ecolology Progress Series 441, 117-128.

Wangensteen, O.S., Turon, X., Pérez-Portela, R., Palacín, C., 2012. Natural or Naturalized? Phylogeography suggests that the abundant sea Urchin Arbacia lixula is a recent colonizer of the Mediterranean. PLoS ONE 7 (9), e45067. http:// dx.doi.org/10.1371/journal.pone.004506. 